\title{
Failure rate of pterygomandibular block in lower third molar extraction procedures
}

\author{
Taxa de falha do bloqueio pterigomandibular nos procedimentos de extração do terceiro \\ molar inferior \\ Tasa de falla del bloqueo pterigomandibular en los procedimientos de extracción del tercer \\ molar inferior \\ María del Pilar Rodríguez SÁNCHEZ \\ Jadison Junio CONFORTE \\ João Paulo BONARDI \\ Débora Bressan GALAFASSI \\ Daniela PONZONI
}

Department of Surgery and Integrated Clinic, Araçatuba School of Dentistry, Univ. Estadual Paulista - UNESP, 16015-050 Araçatuba-SP, Brasil

\begin{abstract}
The aim of this study was to evaluate the anaesthetic failure rate of the pterygomandibular technique with an inferior alveolar nerve block in lower third molar extraction procedures. Materials and Methods: A total of 67 healthy patients (men and women, aged between 18-35 years) requiring third molar extractions were selected from the Discipline of Surgery, of the Araçatuba Dental School. The anaesthetic technique utilised was a pterygomandibular block using 2\% mepivacaine hydrochloride with epinephrine 1:100,000 (Mepivalem®) in a maximum standardised amount of three tubes $(5.4 \mathrm{ml}$ ) per procedure (performed by the same operator). Surgical procedures were initiated after confirming the sensation of anaesthesia in the area anesthetised at the inferior alveolar nerve. Painful symptoms were recorded during surgery. Results: In total, 117 surgical procedures, i.e., 114 exodontias and three coronectomies, were performed. During surgical procedures, four patients reported pain during manoeuvres of odontosection, representing an anaesthetic failure rate of 3.41\%. Alternative techniques utilised in these four patients involved milohioideo nerve, intraligamentaria, and intrapulpal anaesthesia. Conclusion: The success of inferior alveolar nerve block anaesthesia is difficult to predict due to large anatomical variations, and it is difficult to observe via diagnostic means. The relatively low percentage of anaesthetic failure reported in this study may be related to the number of procedures performed.
\end{abstract}

Descriptors: Anesthesia, Dental; Anesthesia, Local; Molar, Third.

\section{Resumo}

O objetivo deste estudo foi avaliar a taxa de falha anestésica da técnica pterigomandibular com bloqueio do nervo alveolar inferior em procedimentos de extração do terceiro molar inferior. Material e Método: um total de 67 pacientes saudáveis (homens e mulheres, com idade entre 18-35 anos) que requeriam extrações do terceiro molar foram selecionados da Disciplina de Cirutgia da Faculdade de Odontologia de Araçatuba. A técnica anestésica utilizada foi um bloqueio pterigomandibular usando cloridrato de mepivacaína a $2 \%$ com epinefrina 1: 100,000 (Mepivalem ${ }^{\circledR}$ ) em uma quantidade máxima padronizada de três tubos $(5,4 \mathrm{ml}$ ) por procedimento (realizado pelo mesmo operador). Os procedimentos cirúrgicos foram iniciados após confirmação da sensação de anestesia na área anestesiada no nervo alveolar inferior. Sintomas dolorosos foram registrados durante a cirurgia. Resultados: No total, foram realizados 117 procedimentos cirúrgicos, isto é, 114 exodontias e três coronectomias. Durante os procedimentos cirúrgicos, quatro pacientes relataram dor durante as manobras de odontossecção, representando uma taxa de falha anestésica de 3,41\%. As técnicas alternativas utilizadas nesses quatro pacientes envolveram nervo milohioideo, intraligamentar e anestesia intrapulpar. Conclusão: o sucesso da anestesia com bloqueio do nervo alveolar inferior é difícil de prever devido a grandes variações anatômicas e é difícil de observar por meio de meios diagnósticos. A porcentagem relativamente baixa de falha anestésica relatada neste estudo pode estar relacionada ao número de procedimentos realizados.

Descritores: Anestesia Dentária; Anestesia Local; Dente Serotino.

\section{Resumen}

El objetivo de este estudio fue evaluar la tasa de falla anestésica de la técnica pterigomandibular con bloqueo del nervio alveolar inferior en procedimientos de extracción del tercer molar inferior. Material y método: un total de 67 pacientes sanos (hombres y mujeres, con edad entre 18-35 años) que requerían extracciones del tercer molar fueron seleccionados de la Disciplina de Cirutía de la Facultad de Odontología de Araçatuba. La técnica anestésica utilizada fue un bloqueo pterigomandibular usando clorhidrato de mepivacaína al $2 \%$ con epinefrina 1 : 100,000 (Mepivalem ${ }^{\circledR}$ ) en una cantidad máxima estandarizada de tres tubos $(5,4 \mathrm{ml}$ ) por procedimiento (realizado por el mismo operador). Los procedimientos quirúrgicos se iniciaron después de confirmar la sensación de anestesia en el área anestesiada en el nervio alveolar inferior. Los síntomas dolorosos se registraron durante la cirugía. Resultados: En total, se realizaron 117 procedimientos quirúrgicos, es decir, 114 exodontias y tres coronectomías. Durante los procedimientos quirúrgicos, cuatro pacientes relataron dolor durante las maniobras de odontosección, representando una tasa de falla anestésica del 3,41\%. Las técnicas alternativas utilizadas en estos cuatro pacientes involucraron nervio milohioideo, intraligamentar y anestesia intrapulpar. Conclusión: el éxito de la anestesia con bloqueo del nervio alveolar inferior es difícil de predecir debido a grandes variaciones anatómicas y es difícil de observar por medio de medios diagnósticos. El porcentaje relativamente bajo de falla anestésica reportada en este estudio puede estar relacionado al número de procedimientos realizados.

Descriptores: Anestesia Dental; Anestesia Local; Tercer Molar.

\section{INTRODUCTION}

Local anaesthesia is the most common and most efficient means for obtaining analgesia during dental procedures, and a regional nerve block is the most frequently performed technique ${ }^{1}$.

Local anaesthetics are competitive antagonists of sodium channels. Their mechanism of action is to bind to these channels to keep them closed, preventing the entry of sodium into the cell, and therefore averting depolarisation and propagation of nerve impulses. Since the receptors are occupied, the rate and degree of depolarisation progressively decreases until failure of the nerve impulse occurs. The anaesthetic's degree of ionisation is closely related to its efficacy ${ }^{2}$. Local anaesthetics are weak bases. When administered, the drug reaches the tissue in an ionized form; however, due to buffering action, it then becomes non-ionised in order to permeate the cells. Administration of anaesthetic in inflamed 
tissues is one of the causes of failure. This is due to the large amount of inflammatory mediators in inflamed tissue, which reduces the $\mathrm{pH}$ of the medium, retaining the anaesthetic in its ionised form. Consequently, anaesthetic cell permeation is prevented and the desired effect cannot be achieved ${ }^{3}$.

An inferior alveolar nerve block, in addition to buccal and lingual nerves, is essential for extraction procedures of third molars because it innervates the pulp, vestibular gingiva, and lingual gingiva of the posterior teeth. The initial success of anaesthesia is defined by the loss of sensitivity of the lip and at the side of the tongue at which the anaesthesia is administered ${ }^{4}$. Although many patients confirm this loss of sensitivity prior to the procedure, they have still reported pain during surgery.

Anaesthetic success is related to the administration technique, duration and extent of the surgical procedure, type of anaesthetic salt used, and the patient's condition ${ }^{2}$. However, despite consideration of all these factors and the selection of the most suitable administration technique, anaesthetic success is not always achieved. Several studies have been conducted to identify the causes of anaesthetic failure, and based on their findings, it appears that the main or physiological causes are anatomical ${ }^{5}$. These include bifurcation of the inferior alveolar nerve, retromolar foramen associated with accessory innervation, double mental foramen, association between the applied technique and bone density, cross-innervation of the incisors, bifurcated mandibular canal, accessory innervation, and presence of local inflammation ${ }^{6-8}$.

The purpose of this study is to evaluate the effectiveness of analgesia during third molar extraction procedures using the pterygomandibular block involving the inferior alveolar, lingual, and buccal nerves.

\section{MATERIAL AND METHOD}

\section{Patients}

This study followed the standards of the Helsinki Declaration of Human Research (2008), and was approved by the Ethics Committee for Research of the Faculty of Dentistry at São Paulo State University, Aracatuba campus (protocol CAAE number: 19688013.7.0000.5420). A total of 67 patients requiring extraction of mandibular third molars participated in the study.

The study was conducted in the surgical clinic of the Araçatuba Faculty of Dentistry, at São Paulo State University. The informed consent form was signed by patients who agreed to participate in the study. Patients included in this study were men and women aged between 18-35 years, with a minimum body weight of $50 \mathrm{~kg}$. They were excluded if they presented with systemic disease or any locoregional complications influencing the repair process. Other exclusion criteria included the following: hypersensitivity reaction to mepivacaine with epinephrine, pregnancy or lactation, pericoronitis, and mistakes in completing the forms for data collection.

All patients received verbal and written information about the study design. Each patient underwent surgery performed by the same surgeon. The procedures were performed under local anaesthesia, in accordance with all biosecurity principles. The surgery initiation site was chosen at random.

\section{Study Design}

The anaesthetic drug administered was $2 \%$ mepivacaine hydrochloride with epinephrine $1: 100,000$ (Mepivalem ${ }^{\circledR}$ ) in a maximum standardized amount of three tubes $(5.4 \mathrm{ml})$ per surgery. If the patient experienced intraoperative pain, an additional amount of local anaesthetic was administered. The anaesthetic technique used in all cases was the pterygomandibular block involving the inferior alveolar, buccal, and lingual nerves, applied with previous aspiration.

A full-thickness mucoperiosteal envelope flap, with an intrasulcular incision from the first to the second molar, and a distal relief incision in the area of the retromandibular trigone, was utilised in all cases. Osteotomy of the occlusal, buccal, and distal regions to the third molar, in addition to the coronary and/or radicular sections, including coronectomy, was performed according to the surgical requirement and procedural planning. This was followed by suturing of the mucoperiosteal flap.

Pain experienced by the patient during each surgical step, and any requirement for supplementary anaesthesia was recorded.

RESULTS

A total of 117 extractions of third inferior molars were performed among 67 patients, by the same surgeon. Indications for dental extraction in three cases were due to malocclusion; in one of these procedures, a coronectomy was performed due to the proximity of the roots to the inferior alveolar nerve. In four cases, extraction was indicated because of dental hygiene difficulties.

The anaesthetic technique utilized in all cases was the pterygomandibular block using $2 \%$ mepivacaine hydrochloride with epinephrine 1:100,000 (Mepivalem ${ }^{\circledR}$ ). None of the patients reported pain during incision or flap detachment. However, pain was recorded during sectioning in four patients $(3.41 \%)$. An alternative technique, the mylohyoid nerve block ${ }^{9}$ was performed in one patient and achieved successful anesthesia. In the other three patients, intraligamentary and intrapulpal anesthesia was performed during the surgical procedure ${ }^{4}$.

When comparing patient gender, of the 117 
procedures performed, $46(39.31 \%)$ were performed in men and $71(60.68 \%)$ were performed in women. both men and women showed a similar proportion of failure $(1.70 \%)$.

\section{DISCUSSION}

The extraction of third molars is always associated with pain and discomfort. To minimize this, an effective anaesthetic technique is essential. In these procedures, the most frequently utilized technique is the pterygomandibular block involving the inferior alveolar, lingual, and buccal nerves. The inferior alveolar nerve block, in particular, is associated with the highest anaesthetic failure rate. This is because the mandible is the most variable bone of the body, and it can be difficult to locating the mandibular foramen. ${ }^{10}$

Sixty-seven men and women were included in this study. A total of 117 tooth extractions were evaluated in order to assess the rate of anaesthetic failure with the inferior alveolar nerve block, and to discuss the most suitable alternative technique for each case of failure. The results reveal a $3.41 \%$ rate of anaesthetic failure; this is lower compared to previous studies. Studies by Blanton and Jeske ${ }^{11}$, Kanna $^{12}$, Vinckier, ${ }^{13}$ and Wong and Jacobsen ${ }^{14}$ reported an anaesthetic failure rate of $13-19 \%, 23 \%$, $10 \%$, and $5-15 \%$, respectively. In the latter study, failure was considered in cases when the block was not achieved within a maximum of 15 minutes ${ }^{14}$. One theory for the failure of the inferior alveolar nerve block is the accessory innervations by the mylohyoid nerve in the lower teeth. This has been shown to originate at the nerve branches entering the lingual surface of the mandible ${ }^{15}$. In the present study, in one of the patients with inferior alveolar nerve block failure, mylohyoid nerve block ${ }^{9}$ was performed as an alternative technique, and successfully achieved anaesthesia. The technique described involves an injection below the mylohyoid muscle, immediately behind the distal root of the first molar ${ }^{15}$. In the three other patients with inferior alveolar nerve block failure, intraligamentary anesthesia was performed; anesthetic solution was administered through the periodontal ligament, while accessing the pulp of the tooth. To accomplish this technique effectively, the needle should be inserted in the long axis of the tooth, with the bevel positioned toward the root; the technique allows rapid anaesthetic initiation $(\sim 30 \mathrm{~s})$. Some authors, such as Meechen ${ }^{16}$ have reported $100 \%$ success rates with this technique before tooth extraction.

The main causes for failure of the inferior alveolar nerve block are anatomical. This is due to the wide anatomical variation of the mandible, and its innervation, since it contains accessory nerves, bifurcated channels, and double foramen. In addition, other failure causes may be related to the volume of the anesthetic solution administered, anesthetic salt concentration, and local inflammatory processes ${ }^{5}$. In this study, the volume and concentration of the anesthetic salt can be excluded as a potential failure factor, since the same amount was administered to all patients. Local inflammatory processes can also be excluded, since no patient presented with this problem in this study.

In this paper, when analyzed anaesthetic failure by gender, both men and women showed a similar proportion of failure with a $1.70 \%$ rate. Therefore, it can be concluded that gender is not a determining factor in anaesthetic failure.

\section{CONCLUSION}

The findings of this study indicate that it is difficult to achieve a $100 \%$ anaesthetic success rate with inferior alveolar nerve block. Although the anaesthetic failure rate in this study was relatively low, this may be due to the number of procedures performed.

\section{REFERENCES}

1. Johnson TM, Badovinac R, Shaefer J. Teaching alternatives to the standard inferior alveolar nerve block in dental education: outcomes in clinical practice. J Dent Educ. 2007; 71(9):1145-52.

2. Giovannitti JA Jr., Rosenberg MB, Phero JC. Pharmacology of local anesthetics used in oral surgery. Oral Maxillofac Surg Clin North Am. 2013; 25(3):453-65.

3. Ueno T, Tsuchiya H, Mizogami M, Takakura K. Local anesthetic failure associated with inflammation: verification of the acidosis mechanism and the hypothetic participation of inflammatory peroxynitrite. J Inflamm Res. 2008; $1: 41-8$.

4. Nusstein JM, Reader A, Drum M. Local anesthesia strategies for the patient with a "hot" tooth. Dent Clin North Am. 2010; 54(2):237-47.

5. Rood JP. Some anatomical and physiological causes of failure to achieve mandibular analgesia. Br J Oral Surg. 1977; 15(1):75-82.

6. Boronat López A, Peñarrocha Diago M. Failure of locoregional anesthesia in dental practice. Review of the literature. Med Oral Patol Oral Cir Bucal. 2006; 11(6):E510-13.

7. Lew K, Townsend G. Failure to obtain adequate anaesthesia associated with a bifid mandibular canal: a case report. Aust Dent J. 2006; 51(1):86-90.

8. Yonchak T, Reader A, Beck M, Meyers WJ. Anesthetic efficacy of unilateral and bilateral inferior alveolar nerve blocks to determine cross innervation in anterior teeth. Oral Surg Oral Med Oral Pathol Oral Radiol Endod. 2001; 92(2):132-35.

9. Pilar R-SMd. Manejo de Accidentes y 
complicaciones en cirugia dentoalveolar. Bogotá: Entereditores; 2008.

10. Holliday R, Jackson I. Superior position of the mandibular foramen and the necessary alterations in the local anaesthetic technique: a case report. Br Dent J. 2011; 210(5):207-11.

11. Blanton PL, Jeske AH. The key to profound local anesthesia: neuroanatomy. J Am Dent Assoc. 2003; 134(6):753-60.

12. Kanaa MD, Whitworth JM, Meechan JG. A prospective randomized trial of different supplementary local anesthetic techniques after failure of inferior alveolar nerve block in patients with irreversible pulpitis in mandibular teeth. $\mathbf{J}$ Endod. 2012; 38(4):421-25.

13. Vinckier F. What is the cause of failure of local anesthesia? Rev Belge Med Dent (1984). 2000; 55(1):41-50.

14. Wong MK, Jacobsen PL. Reasons for local anesthesia failures. J Am Dent Assoc. 1992; 123(1):69-73.

15. Clark S, Reader A, Beck M, Meyers WJ. Anesthetic efficacy of the mylohyoid nerve block and combination inferior alveolar nerve block/mylohyoid nerve block. Oral Surg Oral Med Oral Pathol Oral Radiol Endod. 1999; 87(5):557-63.

16. Meechan JG. Supplementary routes to local anaesthesia. Int Endod J. 2002; 35(11):885-96.

\section{CONFLICTS OF INTERESTS}

The authors declare no conflicts of interests.

\section{CORRESPONDING AUTHOR}

\section{João Paulo Bonardi}

joão_bonardi@hotmail.com
Received 25/06/2018

Accepted 23/08/2018 